\title{
(E)-3-[3-(2-Butoxyquinolin-3-yl)acryloyl]-2-hydroxy- 4H-chromen-4-one
}

\author{
Rodrigo Abonia *, Luisa Gutiérrez, Jairo Quiroga ${ }^{(D)}$ and Braulio Insuasty \\ Department of Chemistry, Universidad del Valle, A. A. 25360 Santiago de Cali, Colombia; \\ luisa.gutierrez@correounivalle.edu.co (L.G.); jairo.quiroga@correounivalle.edu.co (J.Q.); \\ braulio.insuasty@correounivalle.edu.co (B.I.) \\ * Correspondence: rodrigo.abonia@correounivalle.edu.co; Tel.: +57-2-339-3248
}

Received: 25 May 2018; Accepted: 18 June 2018; Published: 21 June 2018

\begin{abstract}
The coumarinyl-quinolinylchalcone hybrid (E)-3-[3-(2-butoxyquinolin-3-yl)acryloyl]2-hydroxy-4H-chromen-4-one $3 \mathbf{b}$ was prepared in good yield from a Claisen-Schmidt condensation reaction between 3-acetyl-4-hydroxy-2H-chromen-2-one $\mathbf{1}$ and 2-butoxyquinoline-3-carbaldehyde 2 in methanol at reflux and catalyzed by $\mathrm{KOH}$ pellets. The structure of the synthesized compound $\mathbf{3 b}$ was fully confirmed by FTIR-ATR, (1D and 2D) NMR experiments, EIMS and elemental analysis.
\end{abstract}

Keywords: coumarinyl-quinolinylchalcone hybrid; Claisen-Schmidt condensation

PACS: J0101

\section{Introduction}

Chalcones are synthetic and naturally occurring $\alpha, \beta$-unsaturated diaryl ketones that have shown a wide spectrum of biological activities, and can act as anti-tubercular [1], anti-inflammatory [2], antimalarial [3], antibacterial [4], antifungal [5], and mainly as antitumor agents [6]. Another important class of heterocyclic system is the coumarin, which consists of a benzene ring fused to a 2-pyrone skeleton, which is present in various natural and synthetic compounds [7]. Molecules based on the coumarin moiety have been extensively studied as pharmacophore agents because of their interesting medical properties, such as their antioxidant [8], antitumor [9], or antimalarial effects [10], among others. On the other hand, quinolines have attracted considerable interest for many years due to their presence in the skeletons of a large number of pharmacologically active substances and natural products (mainly alkaloids) [11]. Quinoline-based chalcones have been found to display antitumor [12], antibacterial [13], and antiulcer activity [14]. Due to the diverse range of biological activities that these three pharmacophores possess, we hypothesized a novel molecular hybrid incorporating chalcone, coumarinyl, and quinolinyl moieties in the structure of product $\mathbf{3 b}$, as a starting point for a future project in the searching for new molecules of therapeutic potential.

\section{Results and Discussion}

Continuing with our studies on the synthetic utility of chalcones, as key precursors for the synthesis of diverse derivatives with interesting biological properties [15-17], herein, we report an efficient synthesis of a novel coumarinyl-quinolinylchalcone hybrid 3 in good yield. Product 3 was obtained from a mixture of 3-acetyl-4-hydroxy-2H-chromen-2-one $\mathbf{1}$ and 2-butoxyquinoline-3-carbaldehyde 2 via a Claisen-Schmidt condensation reaction as shown in Scheme 1. The reaction proceeded in methanol at reflux and was catalyzed by a $\mathrm{KOH}$ pellet. Upon consumption of the starting materials $\mathbf{1}$ and $\mathbf{2}$, after $4 \mathrm{~h}$ of heating (monitored by TLC), the obtained solution was neutralized with acetic acid and isolated by filtration, affording a yellow solid as the new product. 


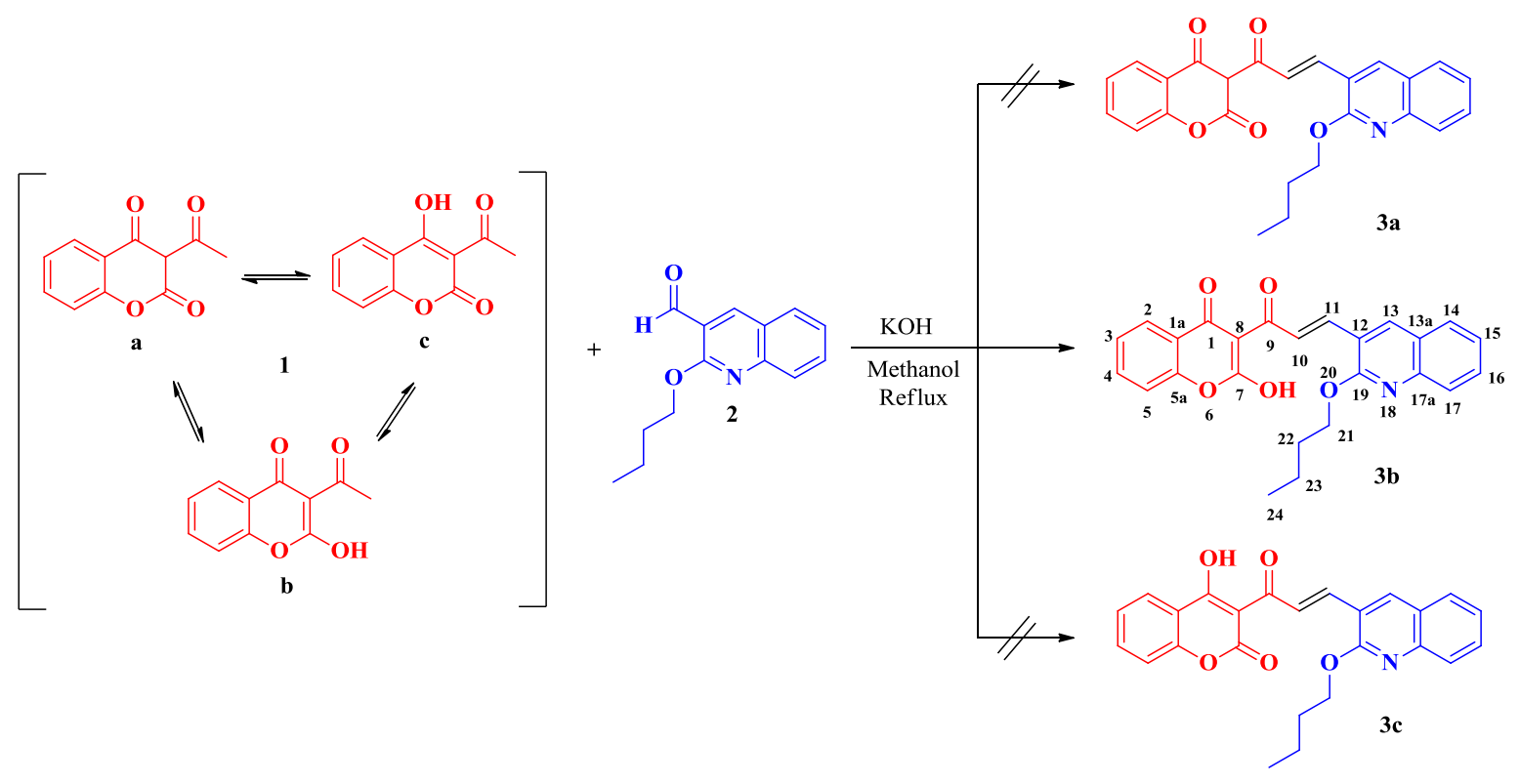

Scheme 1. Synthesis of the coumarinyl-quinolinylchalcone hybrid $\mathbf{3 b}$.

It is well known that the 2,4-dioxocoumarin exist as an equilibrium mixture of their 2,4-dioxo(a), 2-hydroxy-4-oxo- (b) and 4-hydroxy-2-oxo- (c) forms, being this latter the main component of the mixture [18]. In consequence, it is expected that its 3-acetyl derivative $\mathbf{1}$ should exist as the same type of mixtures with the tautomer $1 c$ as the main component [19]. In principle, the IR, 1D NMR, mass spectrum and microanalyses data suggested that effectively the structure of the isolated yellow solid corresponded to the chalcone isomer $3 \mathbf{c}$, taking into account that it proceeded from the majority isomer 1c. Nevertheless, as a challenge, we attempted to assign all protons and carbon atoms from the NMR spectra and mainly by using the 2D HSQC and HMBC experiments, but some drawbacks with structure $3 \mathrm{c}$ were found.

Thus, the most relevant spectroscopic features for the isolated product corresponded to a molecular ion with $m / z 415$ and a base peak with $m / z$ 170, in the mass spectrum, which agree with all three expected isomers 3a-c. The presence of broad absorption bands at $3401 \mathrm{~cm}^{-1}$ and $1735,1711 \mathrm{~cm}^{-1}$ assigned to the $\mathrm{OH}$ and two $\mathrm{C}=\mathrm{O}$ functionalities, respectively, are the most relevant features of the IR spectrum. (Isomers $3 \mathbf{b}$ and $\mathbf{3 c}$ matches with this spectral finding). The presence of a very low field $\mathrm{OH}$ signal at $18.9 \mathrm{ppm}$, as well as, two doublets at $8.37(\mathrm{~J}=15.9 \mathrm{~Hz}, 1 \mathrm{H})$ and 8.74 $(J=15.9 \mathrm{~Hz}, 1 \mathrm{H}) \mathrm{ppm}$ associated with the $\alpha, \beta$-vinylic protons 10 and $11 \mathrm{in} E$ configuration of the new $\mathrm{C}=\mathrm{C}$ bond formed, and the absence of a $8-\mathrm{H}$ aliphatic proton, are the most relevant features of the ${ }^{1} \mathrm{H}-\mathrm{NMR}$ spectrum (just isomers $\mathbf{3 b}$, and $\mathbf{c}$ match with this finding). The presence of ten quaternary Cq carbon atoms involving two $\mathrm{C}=\mathrm{O}$ functionalities at 181.6 and $192.6 \mathrm{ppm}$ are the most relevant features of the ${ }^{13} \mathrm{C}-\mathrm{NMR}$ spectrum. A signal at $192.6 \mathrm{ppm}$ was assigned without doubt to the $\mathrm{C}=\mathrm{C}-\mathrm{C}=\mathrm{O}$ carbonyl moiety. In Addition, only isomers $3 \mathbf{b}, \mathbf{c}$ matched with this finding.

Finally, the proposal of the tautomer $\mathbf{3 b}$ as the true obtained product helped us to solve the above drawbacks. A three bonding correlation of $\mathrm{H}-2$ with the $\mathrm{C}=\mathrm{O}$ functionality at $181.6 \mathrm{ppm}$ and a complete agreement of the remaining 2D NMR correlations in the HMBC experiment confirmed the above. Hence, the signal at $181.6 \mathrm{ppm}$ is associated with the ketonic C-1 carbon atom, indicating that the $\mathrm{OH}$ group is effectively located on $\mathrm{C}-7$ (see $3 \mathbf{b}$ ), and not on $\mathrm{C}-1$ as it would have happened if isomer $3 \mathrm{c}$ would have been obtained. Thus, after a complete study by analytical and spectroscopic techniques, the formation of chalcone $3 \mathbf{b}$ in $75 \%$ yield (but not their isomers $3 \mathbf{a}, \mathbf{3 c}$ ), was determined. Moreover, 1D and 2D NMR experiments permitted us the assignment of all proton and carbon atoms (see experimental), confirming the proposed structure for $\mathbf{3 b}$ without ambiguity. A comparison of our 
carbon atom assignment with the Automatic Evaluation Report from CSEARCH [20] also matched quite well (see Supplementary Materials).

\section{Materials and Methods}

\subsection{General Information}

Melting point was determined on a Büchi melting point B-450 apparatus (Instrumart, South Burlington, VT, USA) and is uncorrected. The IR spectrum was recorded on a Shimadzu FTIR 8400 spectrophotometer by ATR technique (Scientific Instruments Inc., Seattle, WA, USA). ${ }^{1} \mathrm{H}$ and ${ }^{13} \mathrm{C}-\mathrm{NMR}$ spectra were recorded on a Bruker Avance 400 spectrophotometer (Bruker BioSpin $\mathrm{GmbH}$, Rheinstetten, Germany), operating at $400 \mathrm{MHz}$ and $100 \mathrm{MHz}$, respectively, while using $\mathrm{CDCl}_{3}$ as solvent and tetramethylsilane as the internal standard. Mass spectrum was run on a SHIMADZU-GCMS 2010-DI-2010 spectrometer (Scientific Instruments Inc., Columbia, WA, USA) (equipped with a direct inlet probe) operating at $70 \mathrm{eV}$. Microanalyses was performed on an Agilent CHNS elemental analyzer (Thermo Fischer Scientific Inc., Madison, WI, USA) and the values are within $\pm 0.4 \%$ of the theoretical values.

\subsection{Synthesis of ((E)-3-(3-(2-Butoxyquinolin-3-yl)acryloyl)-2-hydroxy-4H-chromen-4-one (3b)}

A mixture of acetyl-4-hydroxy-2H-chromen-2-one $1(0.1 \mathrm{~g}, 1.0 \mathrm{mmol}), 2$-butoxyquinoline3-carbaldehyde $2(1.1 \mathrm{mmol})$ and a $\mathrm{KOH}$ pellet in methanol $(5 \mathrm{~mL})$ was heated to reflux for $4 \mathrm{~h}$. After disappearance of the starting materials, as monitored by TLC, acetic acid was added portion-wise with stirring, to the reaction mixture until formation of a precipitate. The solid was collected by filtration and washed with cold methanol $(2 \times 0.5 \mathrm{~mL})$ to afford $3 \mathbf{b}(75 \%$ yield, yellow solid, m.p. 180-182 $\left.{ }^{\circ} \mathrm{C}\right)$. FTIR-ATR: $v=3401 \mathrm{br}(\mathrm{OH}), 2961,1735(\mathrm{C}=\mathrm{O}), 1711(\mathrm{C}=\mathrm{O}), 1603(\mathrm{C}=\mathrm{N}), 1565(\mathrm{C}=\mathrm{C}), 1489$, 1424, $(1305,1257,1220,1176,1098)(\mathrm{C}-\mathrm{O}), 989 \mathrm{~cm}^{-1} .{ }^{1} \mathrm{H}-\mathrm{NMR}\left(400 \mathrm{MHz}, \mathrm{CDCl}_{3}\right): \delta=1.08(\mathrm{t}, J=7.4 \mathrm{~Hz}$, $3 \mathrm{H}, \mathrm{H}-24), 1.59-1.66$ (m, 2H, H-23), 1.95-2.03 (m, 2H, H-22), 4.63 (t, J = 6.7 Hz, 2H, H-21), 7.30-7.40 (m, 3H, H-15, H-3, H-5), 7.62-7.70 (m, 2H, H-4, H-16), 7.77-7.81 (m, 2H, H-14, H-17), 8.10 (dd, J = 7.9, $1.7 \mathrm{~Hz}, 1 \mathrm{H}, \mathrm{H}-2), 8.33$ (d, $J=15.9 \mathrm{~Hz}, 1 \mathrm{H}, \mathrm{H}-11), 8.38$ (s, 1H, H-13), 8.70 (d, J = 15.9 Hz, 1H, H-10), $18.90(\mathrm{~s}, 1 \mathrm{H}, \mathrm{OH}) \mathrm{ppm} .{ }^{13} \mathrm{C}-\mathrm{NMR}\left(100 \mathrm{MHz}, \mathrm{CDCl}_{3}\right): \delta=13.9(\mathrm{C}-24), 19.5(\mathrm{C}-23), 30.9(\mathrm{C}-22), 66.6(\mathrm{C}-21)$, 100.9 (C-8), 116.3 (C-1a), 117.0 (C-5), 120.0 (C-12), 124.4 (C-3), 124.6 (C-15), 124.9 (C-13a), 125.1 (C-10), 125.8 (C-2), 127.0 (C-17), 128.4 (C-14), 131.2 (C-16), 136.0 (C-4), 139.5 (C-13), 141.6 (C-11), 147.6 (C-17a), 154.8 (C-5a), 160.1 (C-19, C-7), 181.6 (C-1), 192.6 (C-9) ppm. Anal. calcd. for $\mathrm{C}_{25} \mathrm{H}_{21} \mathrm{NO}_{5}$ (415.44): C, 72.28; H, 5.10; N, 3.37. Found: C, 72.05; H, 4.98; N, 3.51. MS (EI, $70 \mathrm{eV)} \mathrm{m} / z(\%): 415$ (26) [M+], 397 (17), 386 (9), 359 (29), 226 (19), 170 (100), 121 (14), 41 (26).

Supplementary Materials: The following are available online. Figure S1: ${ }^{1} \mathrm{H}-\mathrm{NMR}$ spectrum of compound $\mathbf{3 b}$ in $\mathrm{CDCl}_{3}$, Figure S2: ${ }^{13} \mathrm{C}-\mathrm{NMR}$ spectrum of compound $3 \mathbf{b}$ in $\mathrm{CDCl}_{3}$, Figure S3: DEPT-135 experiment of compound $\mathbf{3 b}$, Figure S4: $\mathrm{HMBC}$ experiment of compound $\mathbf{3} \mathbf{b}$ in $\mathrm{CDCl}_{3}$, Figure S5: Expansion 1 of $\mathrm{HMBC}$ experiment of compound $\mathbf{3 b}$ in $\mathrm{CDCl}_{3}$, Figure S6: Expansion 2 of $\mathrm{HMBC}$ experiment of compound $\mathbf{3 b}$ in $\mathrm{CDCl}_{3}$, Figure S7: Expansion 3 of $\mathrm{HMBC}$ experiment of compound $\mathbf{3} \mathbf{b}$ in $\mathrm{CDCl}_{3}$, Figure S8: HSQC experiment of compound $\mathbf{3 b}$ in $\mathrm{CDCl}_{3}$, Figure S9: Expansion of HSQC experiment of compound $\mathbf{3 b}$ in $\mathrm{CDCl}_{3}$, Figure S10: COSY experiment of compound $\mathbf{3} \mathbf{b}$ in $\mathrm{CDCl}_{3}$, Figure S11: Expansion of COSY experiment of compound $\mathbf{3 b}$ in $\mathrm{CDCl}_{3}$, Figure S12: Mass spectrum of compound $\mathbf{3} \mathbf{b}$ (EI technique), Figure S13: IR spectrum of compound $\mathbf{3 b}$ (ATR technique).

Author Contributions: R.A. designed the experiments; L.G. performed the experiments; R.A., L.G., J.Q. and B.I. analyzed the IR, MS and NMR spectral data and wrote the manuscript. All authors read and approved the final manuscript.

Funding: This research was funded by COLCIENCIAS, grant number 110665842661. APC was sponsored by MDPI.

Acknowledgments: Authors thank COLCIENCIAS and Universidad del Valle for financial support-Project Number CI-7907. L.G. specially thank COLCIENCIAS for her "Joven Investigador" fellowship assigned.

Conflicts of Interest: The authors declare no conflict of interest. 


\section{References}

1. Lin, Y.M.; Zhou, Y.; Flavin, M.T.; Zhou, I.M.; Nie, W.; Chen, F.C. Chalcones and flavonoids as anti-tuberculosis agents. Bioorg. Med. Chem. 2002, 10, 2795-2802. [CrossRef]

2. Won, S.-J.; Liu, C.-T.; Tsao, L.-T.; Weng, J.-R.; Ko, H.-H.; Wang, J.-P.; Lin, C.-N. Synthetic chalcones as potential anti-inflammatory and cancer chemopreventive agents. Eur. J. Med. Chem. 2005, 40, 103-112. [CrossRef] [PubMed]

3. Liu, M.; Wilairat, P.; Go, M.-L. Antimalarial alkoxylated and hydroxylated chalcones: Structure-activity relationship analysis. J. Med. Chem. 2001, 44, 4443-4452. [CrossRef] [PubMed]

4. Ávila, H.P.; Smânia, E.D.F.A.; Delle-Monache, F.; Júnior, A.S. Structure-activity relationship of antibacterial chalcones. Bioorg. Med. Chem. 2008, 16, 9790-9794. [CrossRef] [PubMed]

5. Sivakumar, P.M.; Muthu-Kumar, T.; Doble, M. Antifungal activity, mechanism and QSAR studies on chalcones. Chem. Biol. Drug Des. 2009, 74, 68-79. [CrossRef] [PubMed]

6. Modzelewska, A.; Pettit, C.; Achanta, G.; Davidson, N.E.; Huang, P.; Khan, S.R. Anticancer activities of novel chalcone and bis-chalcone derivatives. Bioorg. Med. Chem. 2006, 14, 3491-3495. [CrossRef] [PubMed]

7. Wei, H.; Ruan, J.; Zhang, X. Coumarin-chalcone hybrids: Promising agents with diverse pharmacological properties. RSC Adv. 2016, 6, 10846-10860. [CrossRef]

8. Xi, G.-L.; Liu, Z.-Q. Coumarin moiety can enhance abilities of chalcones to inhibit DNA oxidation and to scavenge radicals. Tetrahedron 2014, 70, 8397-8404. [CrossRef]

9. Emami, S.; Dadashpour, S. Current developments of coumarin-based anti-cancer agents in medicinal chemistry. Eur. J. Med. Chem. 2015, 102, 611-630. [CrossRef] [PubMed]

10. Sashidhara, K.; Kumar, A.; Dodda, R.; Krishna, N.; Agarwal, P.; Srivastava, K.; Puri, S. Coumarin-trioxane hybrids: Synthesis and evaluation as a new class of antimalarial scaffolds. Bioorg. Med. Chem. Lett. 2012, 22, 3926-3930. [CrossRef] [PubMed]

11. Marella, A.; Tanwar, O.; Saha, R.; Ali, M.; Srivastava, S.; Akhter, M.; Shaquiquzzaman, M.; Alam, M. Quinoline: A versatile heterocyclic. Saudi Pharm. J. 2013, 21, 1-12. [CrossRef] [PubMed]

12. Kotra, V.; Ganapaty, S.; Adapa, S. Synthesis of a new series of quinolinyl chalcones as anticancer and anti-inflammatory agents. Indian J. Chem. 2010, 49, 1109-1116.

13. Abdullah, M.; Mahmood, A.; Madni, M.; Masood, S.; Kashif, M. Synthesis, characterization, theoretical, anti-bacterial and molecular docking studies of quinoline based chalcones as a DNA gyrase inhibitor. Bioorg. Chem. 2014, 54, 31-37. [CrossRef] [PubMed]

14. Sashidhara, K.; Avula, S.; Mishra, V.; Palnati, G.; Singh, L.; Singh, N.; Chhonker, Y.; Swami, P.; Bhatta, R.; Palit, G. Identification of quinoline-chalcone hybrids as potential antiulcer agents. Eur. J. Med. Chem. 2015, 89, 638-653. [CrossRef] [PubMed]

15. Abonia, R.; Cuervo, P.; Insuasty, B.; Quiroga, J.; Nogueras, M.; Cobo, J.; Meier, H.; Lotero, E. An Amberlyst- $15^{\circledR}$ mediated synthesis of new functionalized dioxoloquinolinone derivatives. Open Org. Chem. J. 2008, 2, $26-34$. [CrossRef]

16. Abonia, R.; Cuervo, P.; Insuasty, B.; Quiroga, J.; Nogueras, M.; Cobo, J. A simple two-step sequence for the synthesis of novel 3-aryl[1,3]dioxolobenzo[f]pyrrolo[1,2-a]azepin-11-ones from 6-amino-3,4-methylenedioxyacetophenone. Eur. J. Org. Chem. 2008, 2008, 4684-4689. [CrossRef]

17. Abonia, R.; Insuasty, D.; Castillo, J.; Insuasty, B.; Quiroga, J.; Nogueras, M.; Cobo, J. Synthesis of novel quinoline-2-one based chalcones of potential anti-tumor activity. Eur. J. Med. Chem. 2012, 57, $29-40$. [CrossRef] [PubMed]

18. Abdou, M.; El-Saeed, R.; Bondock, S. Recent advances in 4-hydroxycoumarin chemistry. Part 1: Synthesis and reactions. Arab. J. Chem. 2015. [CrossRef]

19. Abdou, M. 3-Acetyl-4-hydroxycoumarin: Synthesis, reactions and applications. Arab. J. Chem. 2017, 10, S3664-S3675. [CrossRef]

20. Please See CSEARCH-Robot-Referee by Haider, N.; Robien, W. Available online: http:/ / nmrpredict.orc. univie.ac.at/c13robot/robot.php (accessed on 15 June 2018).

(C) 2018 by the authors. Licensee MDPI, Basel, Switzerland. This article is an open access article distributed under the terms and conditions of the Creative Commons Attribution (CC BY) license (http://creativecommons.org/licenses/by/4.0/). 